\title{
Migration of Rural Residents in Russia's Regions: Issues, Trends, and Focus Areas
}

\author{
E.S. Kovanova ${ }^{1^{*}}$, N.V. Badmaeva ${ }^{2,3}$ \\ ${ }^{1}$ Department of Economic Security, Accounting, and Finance, Kalmyk State University named after B.B. Gorodovikov, Pushkin Street, \\ 11, Elista, Republic of Kalmykia, 358000, Russian Federation \\ ${ }^{2}$ Department for Comprehensive Monitoring and Information Technologies, Kalmyk Scientific Center of the RAS, I.K. Ilishkina Street, 8 , \\ Elista, Republic of Kalmykia, 358000, Russian Federation \\ ${ }^{3}$ Kalmyk State University named after B.B. Gorodovikov, Pushkin Street, 11, Elista, Republic of Kalmykia, 358000, Russian Federation \\ *Corresponding author E-mail: kovanova.e.s@mail.ru
}

\begin{abstract}
This paper relies on statistical information to investigate the relevant issue of rural migration across Russia's federal districts. Migration by rural residents may lead to declines in the relative share of rural residents in the nation's social structure, intensify its urbanization processes, cause rural depopulation, and result in declines in the demographic potential of rural areas. These processes are associated with profound social and economic issues facing the Russian countryside.
\end{abstract}

Keywords: Causes of migration; Federal districts; Internal labor migration; Migration; Rural residents; Unemployment.

\section{Introduction}

In today's world, migration is one of the key regulators of demographic, social, economic, and ethnical processes. Among the numerous dimensions in present-day migration, migration by rural residents continues to play a significant role in the socio-economic development of various nations. The intensity of migration processes and where migration is directed are indicators of various social, economic, and demographic issues in regions where migration takes place, on the one hand, and of the economic attractiveness of receiving regions, on the other hand.

Rural migration is interrelated with the issue of rational allocation and use of labor resources. Processes of migration among rural residents are investigated within the context of internal migration, urbanization, labor migration, migration by youth, etc.

Demographic processes in Russia's present-day countryside are characterized by profound depopulation trends. But the process of depopulation in rural areas is by no means a unique Russian phenomenon - it is largely similar to these processes in other countries. The share of rural residents constitutes $28.2 \%$ of the population in the European Union [1] (France - 20\%, Germany - 24\%, Portugal $-36 \%$, Italy $-31 \%$, and the UK $-17 \%$ [2], $18 \%$ in the US and Canada, $14 \%$ in Brazil, $26 \%$ in Turkey, $6 \%$ in Japan [2], $43.9 \%$ in China [3], and $68.9 \%$ in India [4].

However, it should be noted that in Western countries declines in the number of rural residents are not always the result of migration and drops in the birth rate due to a complicated socio-economic situation. For instance, in certain countries the size of the rural population may change due to implementation of new technology within the agricultural sector, changes in the status of suburban areas, and some other reasons. Russia is currently characterized by an unregulated mass exodus of able-bodied residents to cities and extremely high concentrations of residents in the capital and a few other large cities.
The complicated socio-economic situation in the country has led to declines in the standard of living of rural residents and their material well-being, fewer opportunities to get a job, and, consequently, mass migration to cities, megalopolises, and other better situated and better developed regions. Migration can also be induced by issues related to destruction of rural social infrastructure. All this has led to a major portion of the population getting deprived of access to many of the social, medical, and cultural/educational services. There are fewer opportunities for the young generation to get a decent education and find a suitable occupation. At the same time, the process of reforming the agricultural sector is being implemented today with great difficulty, with large agricultural enterprises experiencing declines in growth and many farming (peasant) enterprises having yet to gain a firm foothold. This gives relevance to the issue of rural migration, which is having an effect on the total size of the rural population, their age structure, the structure of the economically active portion of the population (which has an effect on areas' demographic and labor potential), the state of the agro-industrial complex, and the economy of agriculture in regions as a whole.

\section{Methods}

To investigate the nation's rural migration processes, the authors analyzed statistical information from the Russian Federal State Statistics Services on Russia's federal districts covering the period from 2012 to 2017 . The authors examined the following statistical indicators: relative share of urban and rural residents, overall birth coefficients, unemployment by settlement type, migration inside Russia by areas of inbound and outbound migration from rural to urban areas and rural to rural areas, and some others. 


\section{Results and Discussion}

In present-day Russia, a federal district acts as a basic structural unit in division into districts, is a territorial category that reflects the state of production forces and natural, historical, economic, and some other characteristics, and is the territorial/administrative basis for management of socio-economic processes in regions. We will first examine the size of Russia's population by its federal districts (Table 1).

Table 1: Russia's Population by Its Federal Districts (as of January 1, 2017) [5]

\begin{tabular}{|c|c|}
\hline & $\begin{array}{c}\text { Population size } \\
\text { (thousand people) }\end{array}$ \\
\hline Russian Federation & 146,804 \\
\hline Central Federal District & 39,209 \\
\hline Northwestern Federal District & 13,899 \\
\hline Southern Federal District & 16,429 \\
\hline North Caucasian Federal District & 9,776 \\
\hline Volga Federal District & 29,637 \\
\hline Ural Federal District & 12,345 \\
\hline Siberian Federal District & 19,326 \\
\hline Far Eastern Federal District & 6,183 \\
\hline
\end{tabular}

The most populous are the Central Federal District and the Volga Federal District. With that said, over 12,380,000 people reside in Moscow [6] which is part of the Central Federal District. The size of the population of Saint Petersburg, which is part of the Northwestern Federal District, is over 5,281,000 people [7].

The share of rural residents in Russia has been quite stable over the last few decades, with intensive processes of urbanization being a matter of the past now. Starting in the 1990s, the ratio of urban to rural residents has fluctuated at the level $73-74 \%$ to $26-$ $27 \%$. For instance, based on census data, the relative share of rural residents in 1989 was $26.6 \%$, in $2002-26.7 \%$, and in $2010-26.3 \%$ [8]. Starting in 2012, the relative share of rural residents dropped from $26.1 \%$ to $25.7 \%$ in 2017 [5].

Russia's dynamics of rural population size are distinguished by tangibly distinct regional characteristics. Table 2 illustrates the ratio of urban and rural residents across the nation's federal districts.
Table 2: Relative Share of Urban and Rural Residents in the Total Size of Russia's Population by Its Federal Districts in 2016

(as at year-end 2016, \%) [9]

\begin{tabular}{|c|c|c|}
\hline & Urban residents & Rural residents \\
\hline Russian Federation & 74.3 & 25.7 \\
\hline Central Federal District & 82.1 & 17.9 \\
\hline Northwestern Federal District & 84.3 & 15.7 \\
\hline Southern Federal District & 62.4 & 37.6 \\
\hline North Caucasian Federal District & 49.1 & 50.9 \\
\hline Volga Federal District & 71.7 & 28.3 \\
\hline Ural Federal District & 81.2 & 18.8 \\
\hline Siberian Federal District & 73.0 & 27.0 \\
\hline Far Eastern Federal District & 75.7 & 24.3 \\
\hline
\end{tabular}

The greatest share of rural residents was registered in the following federal districts: North Caucasian (50.9\%), Southern $(37.6 \%)$, and Volga (28.3\%). The lowest share was recorded in the following federal districts: Northwestern (15.7\%), Central (15.7\%), and Ural (18.8\%)

The Center for Economic and Political Reforms has noted a significant decline in the size of the rural population in the Central, Northwestern, Volga, Siberian, and Far Eastern federal districts in the period between the 2002 and 2010 population censuses. With that said, there was recorded an increase in the number of rural residents in the Ural, Southern, and North Caucasian federal districts. In the following years, all the federal districts, except for the North Caucasian federal district, are exhibiting a continual decline in the number of rural residents [8]. In this regard, it is worth noting that in all the federal districts under examination the relative share of rural residents has declined year by year owing to internal migration. In the North Caucasian Federal District, the relative share of rural residents grows mainly owing to a high birth rate. The federal district is placed first in terms of the total birth coefficient per 1,000 born residents, which for this federal district is 15.9 [9].

However, the North Caucasian district's high birth rates and complicated socio-economic situation are resulting in surplus manpower and unemployment in the North Caucasian Federal District. An analysis of the composition of the segment of unemployed residents in the federal districts by settlement type indicates that the greatest number of unemployed rural residents is registered in the North Caucasian, Southern, Far Eastern, and Siberian federal districts. The lowest number is recorded in the Ural Federal District, where the share of rural residents does not exceed 19\% [10] Table 3 lists the major directions for internal migration by rural residents in the federal districts from rural to urban areas and from rural to rural areas.

Table 3: Population Migration inside Russia by Areas of Inbound and Outbound Migration in 2016 across Its Federal Districts (from Rural to Urban Areas) [11]

\begin{tabular}{|c|c|c|c|c|c|c|c|c|c|}
\hline $\begin{array}{c}\text { Area of inbound } \\
\text { migration }\end{array}$ & $\begin{array}{c}\text { Russian } \\
\text { Federation }\end{array}$ & CFD & NWFD & SFD & NCFD & VFD & UFD & SFD & FEFD \\
\hline $\begin{array}{c}\text { Central Federal } \\
\text { District }\end{array}$ & 193,239 & 165,881 & 8,922 & 4,764 & 1,436 & 5,917 & 2,455 & 2,148 & 1,716 \\
\hline Northwestern Federal District & 78,699 & 5,941 & 66,250 & 1,553 & 542 & 2,223 & 768 & 923 & 499 \\
\hline $\begin{array}{c}\text { Southern Federal } \\
\text { District }\end{array}$ & 107,206 & 13,305 & 5,564 & 72,453 & 3,171 & 3,504 & 4,005 & 2,977 & 2,227 \\
\hline $\begin{array}{l}\text { North Caucasian } \\
\text { Federal District }\end{array}$ & 68,072 & 10,137 & 4,509 & 7,299 & 35,004 & 2,034 & 6,048 & 2,165 & 876 \\
\hline Volga Federal District & 239,246 & 20,622 & 6,733 & 3,307 & 810 & 187,745 & 16,067 & 2,485 & 1,477 \\
\hline Ural Federal District & 70,379 & 2,101 & 1,159 & 1,410 & 323 & 2,679 & 60,424 & 1,766 & 517 \\
\hline $\begin{array}{c}\text { Siberian Federal } \\
\text { District }\end{array}$ & 147,662 & 4,565 & 2,531 & 2,404 & 356 & 1,365 & 5,043 & 127,114 & 4,284 \\
\hline Far Eastern Federal District & 51,070 & 2,082 & 1,298 & 1,378 & 220 & 945 & 501 & 1,795 & 42,851 \\
\hline
\end{tabular}

As is evidenced by the data in the above table, the greatest volume of internal migration from rural to urban areas is recorded in the Central Federal District, the Volga Federal District, and the Siberian Federal District.
We will now examine the most attractive areas for inbound migration by rural residents (Figures 1-3). 


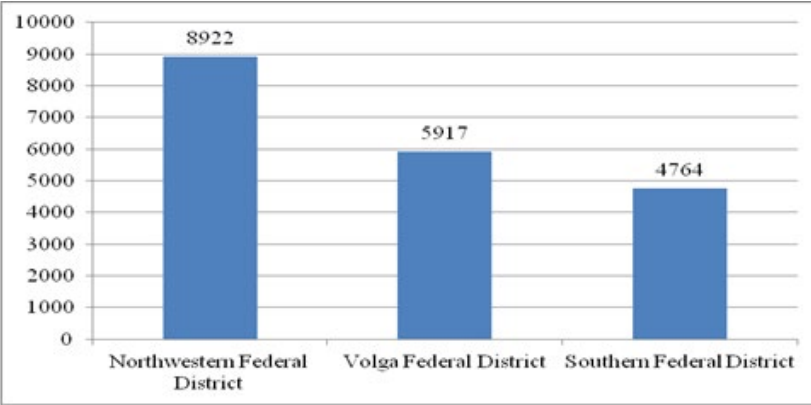

Fig. 1: Major directions for migration from the Central Federal District (from rural to urban areas)

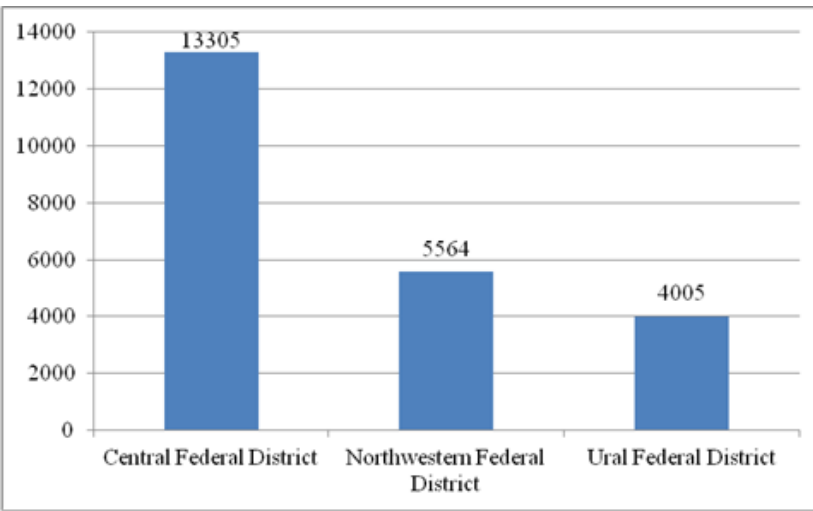

Fig. 2: Major directions for migration from the Southern Federal District (from rural to urban areas)

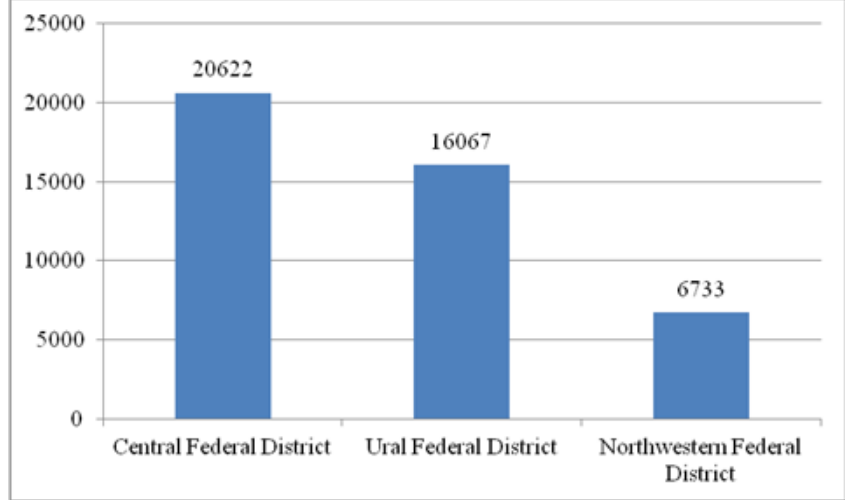

Fig. 3: Major directions for migration from the Volga Federal District (from rural to urban areas)

Across the above directions for rural migration, it is particularly worth mentioning the following centers of attraction: the Central Federal District and the Northwestern Federal District, which incorporate the federal cities Moscow and Saint Petersburg; the Ural Federal District, which encompasses the Urals and Western Siberia and is currently a major industrially and economically developed region. Scholar N.V. Mkrtchyan has characterized the Urals and Western Siberia, which incorporate Yamalo-Nenets Autonomous Okrug and Khanty-Mansi Autonomous Okrug (part of Tyumen Oblast) as the second major center of attraction for migrants behind Moscow and Moscow Oblast [12]. It is also worth noting that migration may take place based on territorial proximity and neighborhood as well.

Table 4 lists the most attractive directions for inbound migration from rural to rural areas across the nation's federal districts.

Table 4: Population Migration inside Russia by Areas of Inbound and Outbound Migration in 2016 across Its Federal Districts (from Rural to Rural Areas) [11]

\begin{tabular}{|c|c|c|c|c|c|c|c|c|c|}
\hline $\begin{array}{c}\begin{array}{c}\text { Area of inbound } \\
\text { migration }\end{array} \\
\begin{array}{c}\text { Area of outbound } \\
\text { migration }\end{array}\end{array}$ & $\begin{array}{c}\text { Russian } \\
\text { Federation }\end{array}$ & CFD & NWFD & SFD & NCFD & VFD & UFD & SFD & FEFD \\
\hline $\begin{array}{l}\text { Central Federal } \\
\text { District }\end{array}$ & 65,436 & 53,622 & 2,064 & 3,368 & 1,458 & 3,340 & 465 & 772 & 347 \\
\hline Northwestern Federal District & 25,334 & 1,924 & 20,514 & 910 & 483 & 990 & 162 & 242 & 109 \\
\hline $\begin{array}{c}\text { Southern Federal } \\
\text { District }\end{array}$ & 51,164 & 3,371 & 1,035 & 39,779 & 3,413 & 1,531 & 726 & 862 & 447 \\
\hline $\begin{array}{l}\text { North Caucasian } \\
\text { Federal District }\end{array}$ & 33,269 & 2,213 & 748 & 4,434 & 23,796 & 1,047 & 455 & 339 & 237 \\
\hline Volga Federal District & 93,117 & 4,661 & 1,405 & 2,294 & 904 & 80,840 & 2,020 & 641 & 352 \\
\hline Ural Federal District & 25,660 & 740 & 253 & 1,066 & 496 & 2,081 & 20,140 & 763 & 121 \\
\hline $\begin{array}{c}\text { Siberian Federal } \\
\text { District }\end{array}$ & 64,135 & 1,362 & 581 & 1,861 & 385 & 794 & 937 & 57,195 & 1,020 \\
\hline Far Eastern Federal District & 17,566 & 509 & 204 & 886 & 184 & 390 & 149 & 802 & 14,442 \\
\hline
\end{tabular}

Rural residents migrate to rural areas 2.5 times less than they do to urban areas. The principal directions for inbound migration are the following districts: Volga, Central, Siberian, and Southern (Figures 4-7).
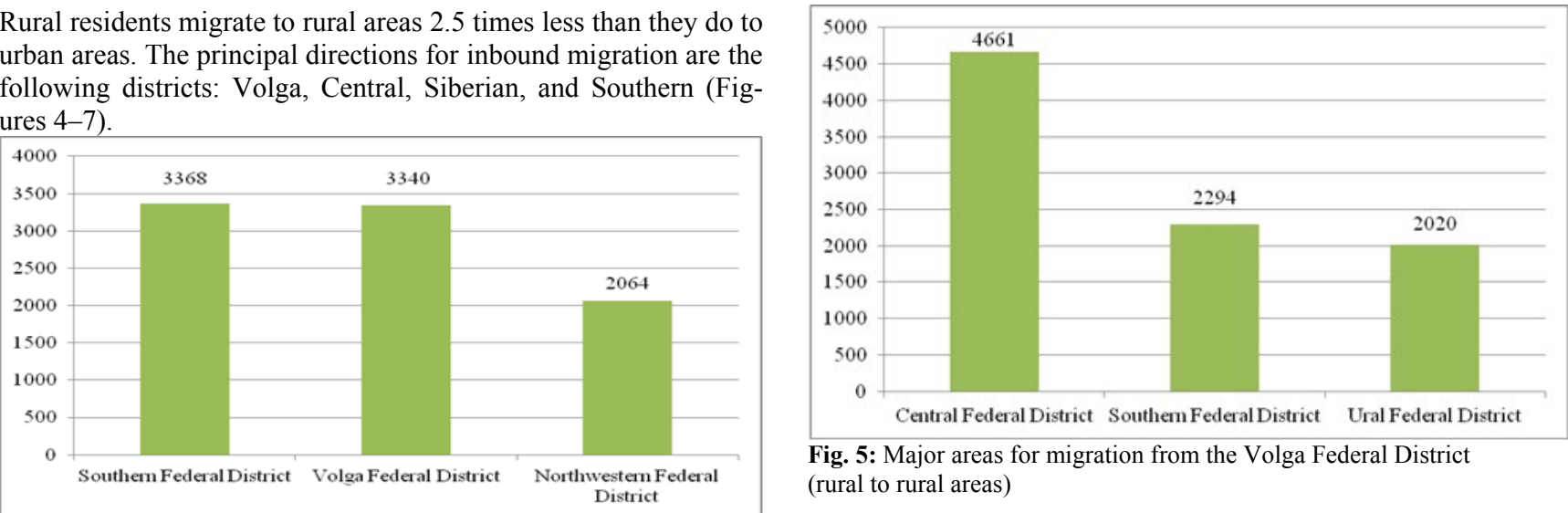

Fig. 5: Major areas for migration from the Volga Federal District (rural to rural areas)

Fig. 4: Major areas for migration from the Central Federal Distric (rural to rural areas) 


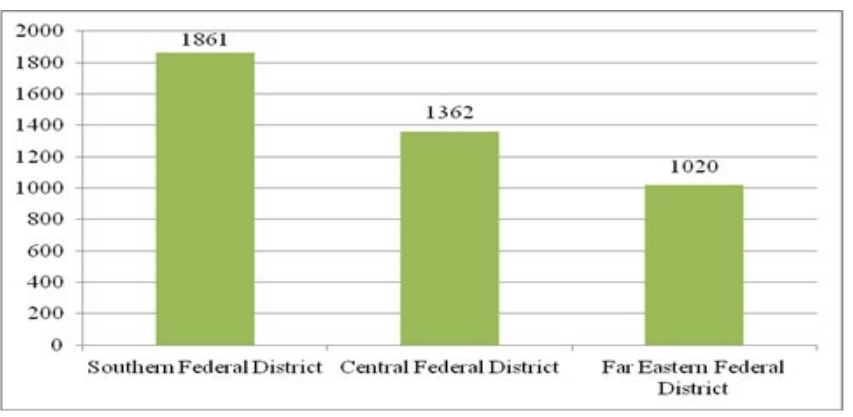

Fig. 6: Major areas for migration from the Siberian Federal District (rural to rural areas)

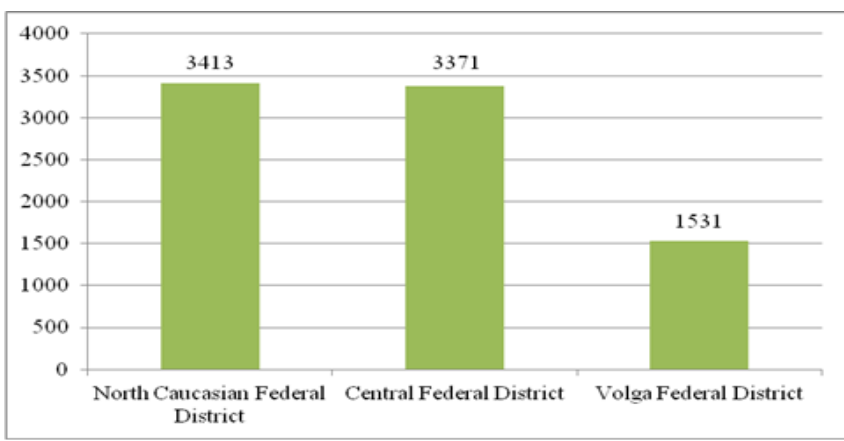

Fig. 7: Major areas for migration from the Southern Federal District (rural to rural areas)

When it comes to directions for the migration of rural residents to rural areas in other federal districts, it, above all, is worth mentioning the Southern Federal District and the Central Federal District. In this case, migration from rural to rural areas is mainly directed not toward industrial centers but toward agricultural regions.

The Central Federal District and the Ural Federal District are leading the way in growth in production and income. They owe their edge mainly to advanced growth demonstrated by the Moscow agglomeration and Yamalo-Nenets Autonomous Okrug and Khanty-Mansi Autonomous Okrug. These regions are centers of attraction for labor migrants and are principal directions for the migration of rural residents from federal districts with high figures on migratory activity [13, p. 99].

In this regard, it may be worth focusing on one of the key issues in internal rural resident migration - territorial socio-economic differentiation among Russia's regions. While there are obvious positive aspects of migration inside the country (e.g., reduced unemployment, boosts in labor productivity and cultural exchange, and boosts in pay), there are a few negative ones as well.

An exodus of rural residents may lead to drops in the labor potential of rural areas and declines in the size of the economically active population.

Among the critical issues facing the countryside today is the massive migratory exodus of youth to cities. This is a mass-scale process now with complicated, negative demographic implications, as it is youth who make up the most able-bodied portion of the population, while youth also account for three-fourths of all child births. The current situation with rural residents leaving and not coming back is posing a huge problem for Russia's agrarian regions [14]. In this regard, a key strategic objective for the nation is to boost the employment rate and enhance its regulation of the labor market in the countryside, which should help change the directions of internal labor migration.

\section{Conclusion}

In Russia, the relative share of rural residents is $26 \%$. Rural residents in almost all of Russia's federal districts, except for the North Caucasian Federal District, are exhibiting a trend toward decline in numbers. An analysis of statistical information indicates that the greater the relative share of rural residents is, the greater the share of those unemployed among rural residents is. Rural residents migrate to rural areas 2.5 times less than they do to urban ones. The migratory directions "rural to urban" and "rural to rural" differ in distinct economic characteristics - and, accordingly, in the economic and infrastructural attractiveness of various regions within the nation's federal districts. From this it may be concluded that rural resident migration may result in declines in the relative share of rural residents within the nation's social structure, intensify its urbanization processes, cause rural depopulation, and result in declines in the demographic potential of rural areas.

\section{References}

[1] EU Open Data Portal (2017), Distribution of population by degree of urbanisation, dwelling type and income group - EU-SILC survey. https:/data.europa.eu/euodp/data/dataset/iI0xc8d81Vp1Wk6EDy1A

[2] The World Bank (2017), Rural population. https://data.worldbank.org/indicator/SP.RUR.TOTL.ZS

[3] National Bureau of Statistics of China (2016), China statistical yearbook 2016. http://www.stats.gov.cn/tjsj/ndsj/2016/indexeh.htm

[4] Central Statistics Office (2017), Selected socio-economic statistics. India 2017. http://www.mospi.gov.in/sites/default/files/publication_reports/Sele ctedSocio-EconomicStatisticsIndia2017_27oct17.pdf

[5] Russian Federal State Statistics Service (2017), Chislennost' naseleniya [Population size]. http://www.gks.ru/wps/wcm/connect/rosstat_main/rosstat/ru/statisti cs/population/demography/\#

[6] Moscow Territorial Body of the Federal State Statistics Service (2018), Otsenka chislennosti postoyannogo naseleniya g. Moskvy [An estimate of the size of Moscow's resident population]. http://moscow.gks.ru/wps/wcm/connect/rosstat_ts/moscow/ru/statis tics/population/

[7] Saint Petersburg Office of the Federal State Statistics Service (2017), Chislennost' naseleniya g. Sankt-Peterburga po stoyaniyu na 1 yanvarya $2017 \mathrm{~g}$. [Size of Saint Petersburg's population as at January 1, 2017]. http://petrostat.gks.ru/wps/wcm/connect/rosstat_ts/petrostat/ru/statis tics/Sant_Petersburg/population/

[8] Center for Economic and Political Reforms (2016), Rossiya - strana umirayushchikh dereven' [Russia - A nation of dying countryside]. https://tinyurl.com/yanzp8pu

[9] Russian Federal State Statistics Service (2017), Demograficheskii ezhegodnik Rossii 2017 [2017 Russia demographics yearbook]. Moscow: Rosstat.

[10] Russian Federal State Statistics Service (2017), Sostav bezrabotnykh po polu $i$ vidu poselenii $v 2016 \mathrm{~g}$. [Unemployment by gender and settlement type in 2016]. http://www.gks.ru/bgd/regl/b17_14p/Main.htm

[11] Russian Federal State Statistics Service (2017), Vnutrirossiiskaya migratsiya naseleniya po territoriyam pribytiya $i$ vybytiya $v 2016$ godu [Migration inside Russia by areas of inbound and outbound migration in 2016]. http://www.gks.ru/wps/wcm/connect/rosstat_main/rosstat/ru/statisti cs/population/demography/\#

[12] Mkrtchyan NV (2016), Vnutrirossiiskaya trudovaya migratsiya: Masshtaby i strukturnye kharakteristiki [Labor migration inside Russia: Its scale and structural characteristics]. Nauchnye Trudy: Institut Narodnokhozyaistvennogo Prognozirovaniya RAN 14, 546561.

[13] Shichkin IA (2015), Migratsiya naseleniya kak faktor vyravnivaniya sotsial'no-ekonomicheskoi differentsiatsii regionov Rossii [Population migration as a factor for evening out the socio-economic differentiation among Russia's regions]. Uroven' Zhizni Naseleniya Regionov Rossii 4, 97-105.

[14] Chapek VN (1983), Migratsiya i stabilizatsiya trudovykh resursov sela [Migration and stabilization of labor resources in the countryside]. Rostov-on-Don, USSR: Izdatel'stvo Rostovskogo Universiteta. 